\title{
1
}

\section{Good government and corruption}

\author{
Barry Hindess
}

Corruption today is commonly understood in economic terms, in relation both to its content (money in exchange for favours) and to its effects (on economic growth, development, and so forth). In other historical contexts, corruption has been understood more generally and I will raise the question of why this narrowly economic perspective has come to be so influential. Other chapters in this collection address the issues of how to identify corruption and how to deal with it when you find it. The aim of this chapter, in contrast, is to stand back from such concerns and to focus instead on how we think about corruption, especially in relation to other aspects of public life. Along the way I will raise some questions about the links between democracy and corruption and suggest ways in which what counts as corruption can be seen as a political issue.

\section{Corruption as an economic issue}

Susan Rose-Ackerman's Corruption and Government (1999) is a useful place to start since it presents a particularly clear example of the modern understanding of corruption as a predominantly economic issue. With only minor variations, her account is one that would be accepted not only by the World Bank and other international financial institutions but also by many aid agencies. Rose-Ackerman begins by asking why it is that so many countries have low or negative rates of economic growth, often in spite of the fact that they are well endowed with natural resources or with a highly educated labour force. She offers two different but complementary answers. One is that such countries have weak and poorly functioning public and private institutions. 
They need institutional reform, but such reform is difficult. Constructing dams, highways, and port facilities is technically straightforward. Reforming government and nurturing a strong private sector are more subtle and difficult tasks that cannot be reduced to an engineering blueprint (Rose-Ackerman 1999:1).

Not so long ago, the assumption that economic growth requires a strong private sector would have been widely disputed, but it is now common currency amongst professional economists, and therefore also amongst the governments and other agencies that they advise. So too, unfortunately, is the economists' disdain for all too many technical skills-such as those involved in managing large-scale construction projects-other than those of their own profession.

Her second answer, of course, is corruption, which she understands as a condition in which people (politicians, public servants, businesses) use their privileged positions in order to pursue economic gain. The problem she identifies here is not the pursuit of self-interest as such but rather the manner in which it is pursued in such cases - that is, through the use of a privileged position. Thus she contrasts the pursuit of self-interest through competitive markets-where, she claims, it 'is transmuted into productive activities that lead to efficient resource use'-with 'situations where people use resources both for productive purposes and to gain an advantage in dividing up the benefits of economic activity-called 'rent-seeking' by economists' (Rose-Ackerman 1999:2). The problem in this latter case is that rentseeking introduces costs and distortions with the result that a country will be 'poorer overall if corruption levels are high' (1999:3).

Rose-Ackerman also acknowledges, of course, that what counts as corruption often depends on the context: 'one person's bribe is another person's gift' (1999:5). Her aim is not to deny the reality of such cultural differences but rather to point out as an economist... when the legacy of the past no longer fits modern conditions' (1999:5). Here, the economist presumes to pass judgment over contemporary cultures and practices, dividing them up into elements that belong in the 'modern' world and those that should be discarded as really belonging in the past. While the latter may not always be seen as forms of corruption, the economist's perspective tells us that they have much the same effect.

Why do I think that this view of corruption is far too narrow? I can answer by way of a few examples, starting with two taken from recent issues of The Washington Post - excerpted in The Guardian Weekly of 9 March 2000. The first is an article on Brazil's civil and military police which claims that 'thousands of brutal slayings around the country are being blamed on corrupt 
civil and military officers'. The second, rather closer to home, refers to 'the worst corruption scandal' in the history of the Los Angeles Police Department. The Washington Post reports the LAPD's own internal inquiry as showing that the problem was caused, in large part, 'by its own poor management and a culture of mediocrity-creating the very conditions necessary for dirty cops to run wild'. Not surprisingly, the LAPD also insists, on the basis of the same inquiry, that 'only a small number of officers were directly involved in corrupt and criminal activities'. It is interesting to speculate about how much comfort the citizens of the United States could be expected to draw from the careful use of the word 'directly' in this last extract (how many employees in a large business organisation deal directly with its customers?).

For my purposes, however, what is most striking about these cases is that the word 'corruption' is used to describe the police activities in question, in spite of the fact that economic gain is obviously not the central issue. Even in Washington, home of the World Bank, there are times when it is clearly recognised that there is more to corruption than the pursuit of financial reward. Rose-Ackerman's treatment of corruption as if it were first and foremost an issue of financial gain and economic effect may not deny the existence of these other forms of corruption but it does suggest that they should be seen as something of a sideline. Thus, one problem with the narrowly economistic understanding of corruption concerns the value judgments - for example, that a few thousand brutal slayings may be ultimately less important than economic growth-which its technical language tends to disguise.

In fact, of course, the value judgments involved here are rather more complex than I have just suggested. On the one hand, it is often assumed that economic growth itself will reduce the incidence of violence in a society, and indeed of corruption more generally. The level of police brutality directed against members of the black community in the United States and the systematic corruption of the political systems in the most developed contemporary societies-Japan and the United States-suggest that this assumption may not be well founded. On the other hand, the contrast between economic and other forms of corruption-which the economistic definition tends to promote-should not be overdrawn. Police brutality is commonly directed against union organisers and other leftists, and against the poor more generally, and in that respect it has an obvious economic significance-although its effects in this regard will often be difficult to quantify. This point brings out another facet of the value judgments disguised in the economistic understanding of corruption-the issues highlighted 
by Rose-Ackerman's discussion are significant, not so much because their economic effects are more substantial than those of other forms of corruption, but rather because they can readily be analysed using the tools of contemporary economic theory. (An unkind critic might go further to suggest that, like the police themselves, economic theory often shows a marked social bias in its effects).

Now consider a few other cases of what some might regard as corruption.

- A government puts pressure on police and judiciary to protect its friends and to penalise its opponents.

- A ruling party appoints judges (at very high salaries) and uses the courts to destroy the political opposition. The practice is not uncommon, but Singapore is perhaps the best known example.

- A government acts illegally - that is, against its own laws-in order to influence the policies of other governments, to destabilise governments that it does not like or to prevent unfriendly governments coming to power. All powerful states do this- the United States is the best known example simply because it is by far the most powerful of all contemporary states and, unlike most other states, it has interests in all parts of the world.

- A government uses its powers to discriminate systematically in favour of some sections of the population and against others. Fiji, Northern Ireland and Quebec are well known contemporary examples, but all governments do this to some degree.

- Politicians and public servants are given high salaries relative to most of the population in order to make them less susceptible to bribes. This is one of the solutions to the problem of corruption canvassed by Rose-Ackerman. Why should one suppose that the political and economic effects of having the ruling stratum cut off from the majority in this way will be less damaging than the effects of bribery? Here, too, it is tempting to think that value judgments, rather than evidence and argument, may be at work.

I'll stop here, but it would not be difficult to extend the list of dubious political practices. What is significant about these examples is that they show how political, how contentious, the idea of corruption can be. Whether the practices I've listed are good or bad for the society in question is a matter of political dispute, and those who favour the latter view might be tempted to describe them as corrupt. But they would not be corrupt in Rose-Ackerman's terms. This point brings out yet another facet of the 
narrowly economistic understanding of corruption, namely, that it focuses on issues that are uncontentious. (Here again, as with the police and economic theory, an unkind critic might be tempted to suggest that this choice too disguises a certain political bias.)

\section{A broader perspective}

One way of taking a broader perspective on these issues is to go back into the history of the idea of corruption. The original, and still the most general use of the idea was to identify damaging impurity, some kind of intrusion or distortion which prevented something from being as it should-a foreign element in a chemical compound or a batch of seeds, stones in a packet of rice, talcum powder in cocaine, decay in meat or vegetables. In the case of government, then, corruption in its most general sense refers to anything that prevents government from being what it should (Euben 1989).

Thus, Aristotle, one of the earliest and most influential of Western political thinkers, distinguishes various forms of government-of oneself, of a household, of a slave or of a state-each of which has its own proper purpose and its own forms of corruption (1988). In his view, then, the government of oneself is corrupted if one gives in to unworthy desires or becomes a slave to one's passions. Again, the government of a household is corrupt if, instead of pursuing the interests of its members, the head of the household - assumed to be a male in Aristotle's discussion - uses his position simply for his own satisfaction. Similarly, if the government of a state pursues factional interests rather than the common interests of the community then it too should be seen as corrupt.

Of course, Aristotle's days are long past but this broad understanding of corruption continued to be influential in the West well into the modern period. Thus, when modern forms of representative government began to emerge towards the end of the eighteenth century many people were concerned that parties would be divisive and lead to the pursuit of merely partisan interests. David Hume, for example, notes that parties are

plants which grow most plentifully in the richest soil; and though absolute governments be not wholly free from them, it must be confessed, that they rise more easily, and propagate themselves faster in free governments, where they always infect the legislature itself, which alone could be able, by the steady application of rewards and punishments, to eradicate them (Hume 1987:55-6).

The most notable feature of this passage is its view of partisan politics as a damaging infection. This fear of what partisanship might do to government is a continuing feature of liberal political thought but, by the end of the 
twentieth century, the term 'corruption' was no longer used to describe it. Another example appears in James Madison's comments on the danger of faction, which date from the early debates around the framing of the American Constitution. Faction, he tells us, is
a number of citizens, whether amounting to a majority or minority of the whole, who are united and actuated by some common impulse...adverse to the rights of other citizens, or to the permanent and aggregate interests of the community (Madison 1857:43).

Notice that, in Madison's view, a faction might well consist of a majority of the population. This raises an obvious issue in the relationship between corruption and democracy since it suggests that the people themselves can be seen as a major source of governmental corruption. In fact, this view of the people has influenced the development of representative government in the West (Hindess 2000), where it is designed to limit the influence of the people themselves on the work of government, and it has been used by states, leaders of coups and the military in many parts of the world.

But, for the moment, the main points to notice are

1. that partisanship in government was once seen as a major source of corruption and even now, in the West, where political partisanship is commonplace, there is still a concern that the ruling party or coalition might go too far;

2. that while 'the common interest' or some such notion may be widely invoked, its substantive content is often a matter of political dispute, and that partisan groups commonly identify themselves as pursuing the common interest while describing their political opponents as representing merely factional interests.

Finally, before moving on to the next section, it is worth noting two further uses of the idea of political impurity. One concerns the identification of alien groups within the community-Albanians in Serbia, Indians in Fiji, Christians in India, etc. The sense of impurity invoked here suggests an obvious political solution, namely, 'ethnic cleansing'. This term may be a recent invention but the practices it refers to have played a major part in the history of the West, as indeed they have in other parts of the world. All contemporary Western states, with the partial exception of Britain-which engaged in extensive ethnic cleansing in other parts of the world-are the products of widespread population clearances (Mann 1999).

The other usage appears in the anti-élitism of populist politics. The underlying message here is that political and other élites pretend to speak for the people while actually representing only themselves-they offer a distorted representation of the common interest. Populism is often regarded 
as a kind of extremism but it is actually an endemic feature of modern politics - in which the rulers of all states claim to act in the interests of the people (Schedler 1997). Most successful political leaders resort to such populist appeals, suggesting that it is their political opponents who are out of touch with the people.

While the word 'corruption' is not often used in these cases, they appeal to the same underlying idea of impurity or distortion. I suggested earlier that the economistic understanding of corruption may be too narrow, that there are important issues which it fails to address. These last two cases suggest that there may be dangers in a broader understanding, that the invocation of impurity or distortion as something which ought to be corrected can sometimes have remarkably destructive effects. It is not obvious that 'corruption', in its most general sense, is necessarily a bad thing.

\section{Why does it matter?}

I have said enough to indicate why the economistic view of corruption may be too limited. I have also suggested, in passing, that going in the other direction may not be without dangers. But I have said very little about how or why this particular understanding of corruption has become so influential. Unfortunately, this question raises the more general issue of the role of economics in contemporary politics - and that is clearly too large an issue to address in a few paragraphs. For the moment, then, let me offer just a couple of observations. One, as in fact I have just suggested, is that the focus on economic corruption is part of a more general shift in governmental thinking over the last 50 years or so-a shift in which economic issues have become increasingly important to governments, so much so, in fact, that they are now widely seen as the central area of government policy.

The other observation is that development agencies were once content to live with a certain amount of corruption-as, indeed, were colonial governments before them-but that they have turned strongly against it over the last 30 years or so. And they have turned against it, not only in the narrow economic sense that I've been disputing, but also more generally. Thus, while not describing such issues in terms of corruption, these agencies now tend to favour human rights, free and fair elections, and so on.

This last development might seem to suggest that my critique has been misdirected, that the economistic understanding which I have disputed has developed alongside a concern for at least some of the issues that I would want to include within a broader understanding of corruption. This, in fact, returns us to the question of the relations between corruption and 
democracy which I mentioned earlier, and we should give some attention to the links that have recently been drawn between them.

Democracy was initially understood as one of only three basic forms of government. Aristotle, for example, defines a state as 'a body of citizens sufficing for the purposes of life' (1988:1275b, 21-2) and he goes on to say that the state may be ruled by the one, the few or the many. The last of these cases, rule by the many, is democracy. The modern idea of government by the people carries a similar sense-it is not a matter of government by a King, dictator or military junta. This idea, that the people are the ultimate source of political legitimacy for governments, raises one of the broader senses of corruption noted earlier: who belongs to the people and who does not-and it is partly for this reason that population cleansing has played such a prominent part in modern history.

But Aristotle was far from being an unequivocal supporter of democracy. On the contrary, all of the Greek philosophers who have anything to say about democracy regarded it as a potential source of a particular kind of political corruption - the corruption of government by the people themselves (Farrar 1988). The idea here is that government by the people is in danger of being dominated by the poor and poorly educated majority, in which case it could be expected to reflect their ignorance and their prejudices and the ambitions of unscrupulous demagogues.

In fact, this negative perception dominated Western discussion of democracy until well into the nineteenth century (Roberts 1994). When modern forms of representative government began to develop around the end of the eighteenth century it was not initially seen as a kind of democracy at all. It did give the people as a whole a limited role in government, and it was seen for that reason as a way of avoiding the kinds of corruption associated with rule by a King or aristocracy (government by the one or the few). But, because it gave the people a very limited role and left the work of government in the hands of a small minority of elected politicians and public servants, it was also seen as a way of avoiding the dangers which had traditionally been associated with democracy. The identification of representative government with democracy was a nineteenth century development, one that involved a radical transformation of the earlier meaning of democracy.

Unfortunately, it soon became clear that, in avoiding one form of political corruption, by the people in general, representative government opened the way for corruption of others kinds, that is, for the corruption of government by professional politicians and public servants-a form of corruption which has been the concern of populist politics on the one side and of public choice theory and contemporary neoliberalism on the other. 
In fact, the history of representative government could be written as the history of attempts to minimise the effects of the new sources of corruption which it creates (Hindess 2000). Populism addresses the issue by attempting to replace professional politicians by politicians of a different kind-that is, by politicians who profess not to be professionals. Liberalism, inheriting the older tradition of distrusting the people, addresses the issue rather differently

1. by instituting a system of checks and balances, rational bureaucratic administration, codes of conduct for politicians and public servants, independent audits, among other things.

2 . by reducing the temptations in various ways-for example, by offering relatively high salaries to elected politicians and public servants.

3. by reducing the opportunities for corrupt practice by taking government out of certain areas and reducing the scope for administrative discretion.

The last two categories are the prime targets of the economistic understanding of corruption, and I'll come back to them in a moment. But first, we should notice that when the World Bank and other agencies favour democracy, what they have in mind is a form of representative government that avoids the forms of corruption associated with dictatorship and military rule while giving a strictly limited role to the people themselves.

Let me conclude by observing that, in addition to the issues noted earlier, there are grounds for thinking that minimising economic corruption may not be the most important issue for government. Consider two possible remedies for economic corruption canvassed by Rose-Ackerman. She suggests that one way of reducing corruption is to reduce the amount of government itself, for example, by privatising government utilities and public services or by limiting the extent to which economic activity is regulated. Rose-Ackerman focuses on the advantages of such developments but they also have disadvantages, and it is far from clear that the former will outweigh the latter. There are, for example, well known problems associated with the process of privatisation itself-developments in Russia since the end of communist rule provide Western media with the most flagrant examples. There are equally well known problems of a decline in certain kinds of standards as a result of privatisation or a reduction of administrative regulation-safety, security of employment, service to less wealthy customers and so forth. My point here is not that privatisation is necessarily bad or that state provision and state regulation are always good. It is simply that minimising certain kinds of corruption should not be the only concern, and it is not obvious that it will always be the most important. 
Another suggested remedy is to ensure that professional politicians and those working at higher levels of the public service receive salaries that are competitive with those in private business. The assumption here, which seems to me prima facie implausible, is that the better off will be less susceptible to bribery. But, even if it does have the desired effect, this remedy has the consequence noted earlier of creating a significant income gap between a cadre of professional politicians and senior public servants on the one hand and the majority of the population on the other. It leads, in other words, to another version of the problem of faction.

This last point brings us back to the older, more general view of corruption noted earlier. In contrast to this view, the economistic understanding of corruption seems both too narrow and too narrowly technical. It is too narrow because a focus on minimising the extent of economic corruption can obscure-and may sometimes exacerbate - more general problems in the workings of government. It is too narrowly technical because the identification of these more general problems depends on how we identify the common interest-and that, as we have seen, is commonly open to dispute. Thus, to treat the problem of corruption as if it were really amenable to technical solution is also to ignore the fundamentally contentious character of political life. 